\title{
УДК 636.09:612.017:616.98:57.083:591.531.2(477)
}

ГОЛІК М.О., e-mail: nikolaygolik03@gmail.com

Управління з безпечності харчових продуктів та захисту споживачів в Ріпкинському районі Чернігівської області

ПОЛУПАН І.М., канд. вет. наук, e-mail: vetmedic@ukr.net,

НИЧИК С.А., д-р вет. наук, e-mail: vet@ivm.kiev.ua

Інститут ветеринарної медицини НААН

ШАРАЙ Я.М., канд. вет. наук, e-mail: vetmarket@ukr.net

ТОВ «Укрветпромпостач»

НЕДОСЕКОВ В.В., д-р вет. наук, e-mail: nedosekov1 @ rambler.ru

Національний університет біоресурсів і природокористування України

\section{ОРАЛЬНА ІМУНІЗАЦІЯ СОБАК ПРОТИ СКАЗУ}

В статті представлені результати польових досліджень оральної вакцинації проти сказу безпритульних собак рекомбінантною антирабічною вакцииною «Броварабіс V-RG» 3 використанням моделі «імунізачія дикої природи». Представлена методика досліджень, відповідно якої передбачено двократне (через 7 днів) розміщення принад з вакииною в місиях скупчення безпритульних собак. Висвітлені результати дослідження індивідуального специфічного імунітету до вірусу сказу у собак з титрами антитіл 1,37-3,37 $\mathrm{MO} / \mathrm{cm}^{3}$ та груповою сероконверсією на рівні $25,0 \%$.

Ключові слова: сказ, собаки, оральна вакцинація, антирабічна вакцина, титр антитіл.

Вступ. Чисельні аналітичні дослідження епізоотичної ситуації зі сказу в Україні свідчать про недостатність застосування заходів для профілактики і боротьби з цим зоонозам [1-4]. Хоча основним джерелом збудника сказу $\epsilon$ червона лисиця, однак епізоотія сказу в Україні характеризується як «природним», так і «міським» проявом із значною кількістю випадків сказу серед котів $(24,5 \%)$ і собак $(18,5 \%)$ [5].

Враховуючи певну недосконалість парентерального шляху введення вакцин для ліквідації сказу серед собак, ВООЗ заохочує дослідження з оральної вакцинації собак (OBC) і розробку більш безпечних та ефективних вакцин i приманок для цього заходу [6].

Дослідження ефективності методу антирабічної оральної вакцинації собак (OBC) у контрольованому експерименті є першим етапом комплексної оцінки придатності методу [7]. Наступним кроком є визначення ефективності антирабічної оральної вакцини для собак у польових умовах [6].

Здійснення цього заходу можливе чотирма шляхами:

- оральна вакцинація домашніх собак, що мають господаря - модель «від дверей до дверей»;

- надання принади собакам безпосередньо на вулиці, незалежно від того належать вони власнику чи безпритульні; 
- забезпечення власників собак принадами в громадських місцях для згодовування своїм собакам вдома - модель «центральні точки»;

- розміщення принад на місцях, де виявлені безпритульні собаки модель «імунізації дикої природи».

Проведення польових випробувань оральної імунізації собак із застосуванням моделі «імунізації дикої природи» передбачає, як одну із основних складових, оцінку популяції безпритульних тварин [8, 9]. Тільки провівши визначення кількості безпритульних собак, у тому чи іншому населеному пункті, можна проводити обрахунок потреби вакцини для пероральної імунізації собак від сказу.

Мета. Розробити методику оральної вакцинації собак проти сказу та провести дослідження ефективності вакцини «Броварабіс V-RG» для безпритульних собак в польових умовах.

Матеріали і методи досліджень. Підрахунок безпритульних собак був проведений в с.м.т. Ріпки 3 використанням методики, яка була розроблена Всесвітнім товариством захисту тварин (WSPA) і схвалена Міжнародною Коаліцією Поводження 3 Тваринами-Компаньйонами (ICAM Coalition) [8]. Враховуючи невеликі розміри с.м.т. Ріпки, населений пункт був розділений на 6 секторів, в яких проводили підрахунок безпритульних собак (рис. 1).

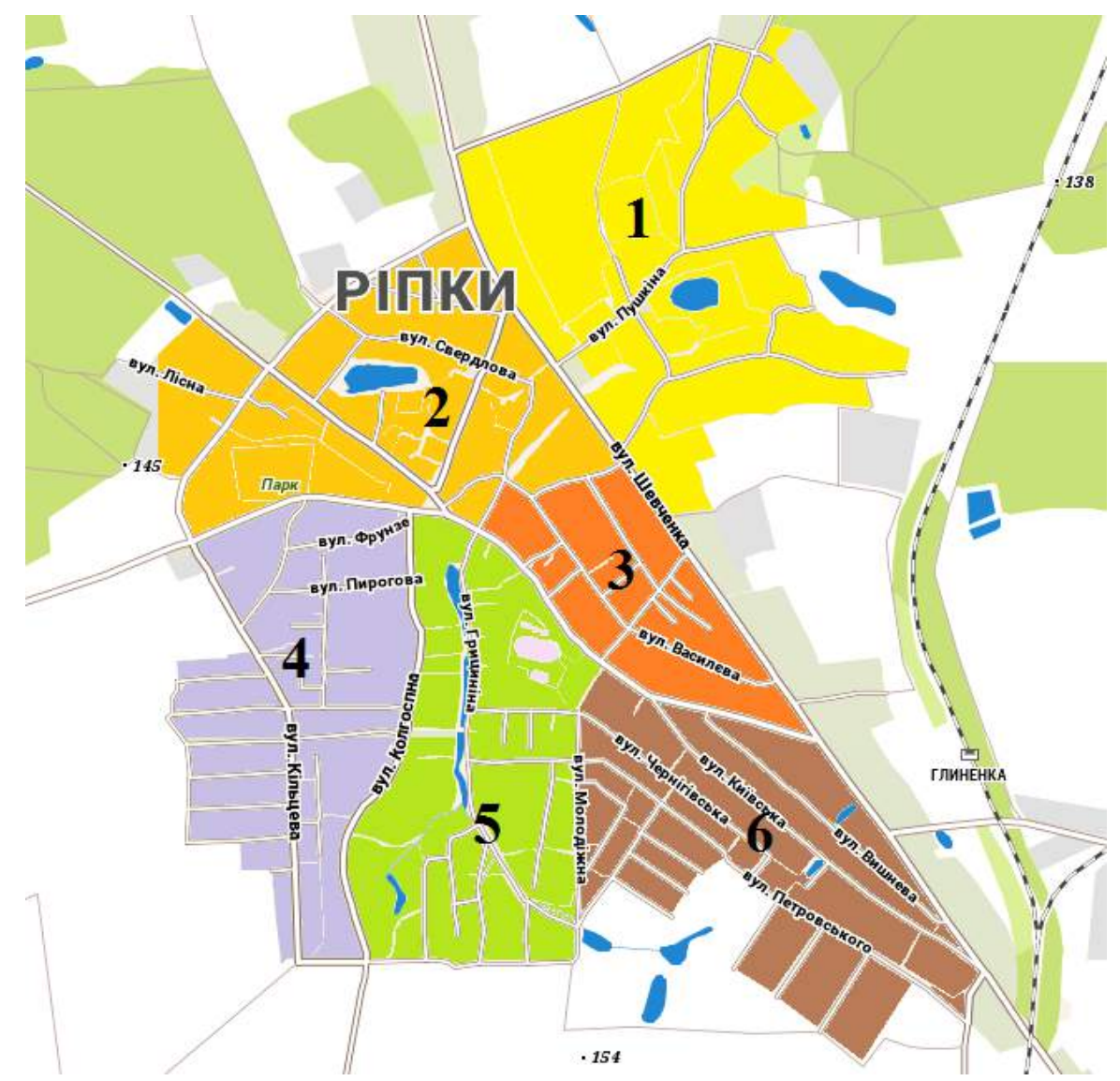

Рис. 1. Карта с.м.т. Ріпки Чернігівської області із зонами обліку безпритульних собак. 
Для пероральної вакцинації було використано 100 (двічі по 50) доз вакцини «Броварабіс V-RG» (серія 030516 із інфекційною активністю в культурі клітин Vero 8,5 lg ТЦД50/доза), яку розкладали по 5 принад з вакциною в 10-и місцях трьох секторів с.м.т. Ріпки Чернігівської області в основних зонах, де було виявлено скупчення безпритульних собак. Через 7 днів аналогічно було проведено повторне розкладання вакцини.

Дослідження напруженості антирабічних антитіл в сироватках крові безпритульних собак, які були відловлені через 30 днів після проведенням розкладання вакцини, здійснювали в реакції нейтралізації [10].

Результати досліджень та їх обговорення. Дослідженнями встановлено кількість безпритульних собак в кожному секторі с.м.т. Ріпки: 1-й сектор - 7; 2-й - 17; 3-й - 11; 4-й - 12; 5-й - 6; 6-й сектор - 9. Загалом, методом обстеження міста виявлено 62 безпритульні собаки. Відповідно використаної методики, похибка досліджень становить $15 \%$, тобто чисельність безпритульних собак може бути близько 72-х особин. Однак, більше 10\% підрахованих собак потенційно мають господаря, тому що багато громадян утримують собак не на прив'язі. Такі тварини можуть вільно переміщатися в межах населеного пункту.

Основна частина безпритульних собак була сконцентрована в центральній частині міста недалеко від місць викидання сміття, біля парку, ринку, а також в межах вул. Шевченка, яка $є$ транзитною дорогою в с.м.т. Ріпки.

Після оцінки популяції безпритульних собак проведено розкладання принад 3 вакциною. Через 24 години проведено обстеження місць, де були розкладені принади з вакциною. Загалом було виявлено 32 дози вакцини (споживання становило $36 \%$ ), які були відібрані й поміщені в холодильник за температури 4-8 ${ }^{\circ} \mathrm{C}$. Через 7 днів проведено повторне розкладання 50-и приманок в тих самих місцях. Аналогічно, через 24 години при здійсненні обліку споживання принад з вакциною виявлено 26 доз, тобто споживання становило $48 \%$. Решту доз вакцини було відібрано й поміщено в холодильник за температури $4-8^{\circ} \mathrm{C}$.

Загалом, після двократного розкладання принад, споживання вакцини “Броварабіс V-RG” становило 42\%. В кількох випадках були виявлені розгризені блістери, а в одному випадку безпосередньо спостерігали споживання безпритульними тваринами принад з вакциною.

В подальшому проведені дослідження популяційного імунітету в безпритульних собак, яких відловили в с.м.т. Ріпки через 30 днів після другого розкладання принад з вакциною. Всього було відловлено 12 собак в секторах № 2 і № 3 (по 6 тварин в кожному), в яких проводили розкладання принад 3 вакциною. У собак були відібрані проби крові, отримані сироватки, в яких досліджено рівні антирабічних антитіл (табл. 1).

Дослідженнями встановлено титри антирабічних антитіл в межах 1,37$3,37 \mathrm{MO} / \mathrm{cm}^{3}$ в трьох пробах сироваток крові безпритульних собак, тобто рівень сероконверсії до вірусу сказу становив 25,0\%. У дев'яти зразках антитіл до вірусу сказу не виявлено. 
Таблиия 1

Рівень антитіл до вірусу сказу в сироватках крові безпритульних собак

\begin{tabular}{|c|c|c|}
\hline \multirow{2}{*}{ № тварини } & \multicolumn{2}{|c|}{ Титр антирабічних антитіл, МО/см } \\
\cline { 2 - 3 } & Сектор № 2 & Сектор № 3 \\
\hline 1 & 0 & 0 \\
\hline 2 & 0 & 0 \\
\hline 3 & 2,38 & 0 \\
\hline 4 & 0 & 3,37 \\
\hline 5 & 0 & 0 \\
\hline 6 & 1,37 & \\
\hline Сероконверсія, \% & \multicolumn{2}{|c}{} \\
\hline
\end{tabular}

Висновки та перспективи подальших досліджень. Проведені дослідження продемонстрували можливість застосування методу оральної вакцинації проти сказу безпритульних собак на території населених пунктів. Дослідження були оформлені актами та будуть основою для відповідних науково-методичних розробок.

\section{СПИСОК ЛІТЕРАТУРИ}

1. Недосєков В.В. Оздоровлення території України від сказу - невідкладні завдання науки і практики / В.В. Недосєков, Л.П. Гришок, І.М. Полупан, М.Ю. Іванов // Ветеринарна медицина України. - 2009. - № 2. - С. 12-13.

2. Гришок Л.П. Проблеми специфічної профілактики сказу домашніх тварин в Україні / Л.П. Гришок, В.В. Недосєков, І.М. Полупан [та ін.] // Ветеринарна медицина України. - 2009. - № 7. - С. 11-13.

3. Голік М. О. Значення різних видів тварин у підтриманні стаціонарнонеблагополучних осередків сказу на території Чернігівської області / М.О. Голік, В.В. Недосєков, І.М. Полупан // Біологія тварин. - 2016. - т. 18. - № 4. - С. 129.

4. Polupan I. Spatial and temporal patterns of enzootic rabies on the territory of Chernihiv oblast of Ukraine / I. Polupan, M.Bezymennyi, M. Golik [et al] // Journal for veterinary medicine, biotechnology and biosafety. - 2017. - Vol. 3. - Iss. 2. - P. 31-36.

5. Голік М. Характеристика епізоотичної ситуації зі сказу в Україні / М. Голік, В. Недосєков, К. Карловська, І. Полупан // Тваринництво України. - 2015. - №. 9. - С. $26-31$.

6. Guidance for research on oral rabies vaccines and Field application of oral vaccination of dogs against rabies // WHO. $-2007 .-57 \mathrm{p}$.

7. Голік М.О. Ефективність пероральної імунізації собак проти сказу вакциною «Броварабіс V-RG» / М.О. Голік, В.В. Недосєков, М.Ю. Іванов [та ін.] // Бюлетень «Ветеринарна біотехнологія». - 2017. - № 30. - С. 41-47.

8. Surveying roaming dog populations: guidelines on methodology. - World Society for the Protection of Animals. - London. - 20 p.

9. Guidelines on stray dog population control. Chapter 7.7. - OIE Terrestrial Animal Health Standards Commission. - 2009. - P. 313-332.

10. Manual of Diagnostic Tests and Vaccines for Terrestrial Animals [Електронний ресурс] // OIE. - $2013 . \quad$ - Режим доступу до ресурсу: http://www.oie.int/fileadmin/Home/eng/Health_standards/tahm/2.01.13_RABIES.pdf.

ОРАЛЬНАЯ ИММУНИЗАЦИЯ СОБАК ПРОТИВ БЕШЕНСТВА / ГОЛИК Н.А., Полупан И.Н., Нычик С.А., Шарай Я.Н., Недосеков В.В.

В статье представлены результаты полевых испытаний оральной вакцинаиии против бешенства бездомных собак рекомбинантной антирабической вакииной 
«Броварабис V-RG» с использованием модели «иммунизачия дикой природыl». Представлена методика исследований, в соответствии с которой предусмотрено двукратное (через 7 дней) размещение приманок с вакииной в местах скопления бездомных собак. Показаны результаты исследования индивидуального специффического иммунитета к вирусу бешенства в собак с титрами антител 1,37-3,37 ME/cм³ и с групповой сероконверсией на уровне $25,0 \%$.

Ключевые слова: бешенство, собаки, оральная вакцинация, антирабическая вакцина, титр антител.

ORAL IMMUNIZATION OF DOGS AGAINST RABIES / Golik M.O., Polupan I.M., Nychyk S.A., Sharai J.M., Nedosekov V.V.

Introduction. Although the main source of rabies in Ukraine is red fox, however, epizooty of the rabies is characterized by "natural" and "urban" manifestation with a significant number of cases in cats (24.5\%) and dogs (18.5\%). Taking into account the certain imperfection of the parenteral route of introducing vaccines, there is a need for studies on oral vaccination of dogs.

The goal of the work. Carry out a study on the effectiveness of the "Brovarabis V-RG" vaccine for stray dogs in the field.

Materials and methods. To evaluate the number of stray dogs we used a methodology developed by the World Society for the Protection of Animals (WSPA). 100 (twice 50) doses of the vaccine "Brovarabis $V$-RG" (series 030516) were used for oral vaccination, which were distributed twice by 5 doses with 7 days interval in 10 different places of three different sectors of Urban-type settlement Ripky in Chernihiv oblast in the areas, where stray dogs was detected. Anti-rabies immunity was evaluated in caught dogs in 30 days.

Results of research and discussion. After town investigation, we detected 62 stray dogs. The majority of the animals was concentrated in the central part of the town not far from the waste disposal sites, near the park and market.

After assessing of the stray dogs population, 50 doses of the vaccine were distributed. After 7 days, 50 vaccine baits where distributed in the same places. In total, 42 of 100 vaccine baits that were distributed twice confirmed to be "lost", which means that consumption rate was $42 \% .12$ dogs were caught to assess anti-rabies immunity. The research revealed titers of anti-rabies antibodies in the range of 1.37-3.37 IU/ $\mathrm{cm}^{3}$ in three blood serum samples of stray dogs, meaning the level of seroconversion to the rabies virus was $25.0 \%$.

Conclusions and prospects for further research. The conducted researches demonstrated the principle possibility of using the method of oral vaccination against rabies of stray dogs in the territory of cities.

Keywords: rabies, dogs, oral vaccination, rabies vaccines, antibody titer.

\section{REFERENCES}

1.Nedosiekov, V.V., Hryshok, L.P., Polupan, I.M. \& Ivanov, M.Yu. (2009). Ozdorovlennia terytorii Ukrainy vid skazu - nevidkladni zavdannia nauky i praktyky [Recovery from rabies in Ukraine - than urgent task of science and practice]. Veterynarna medytsyna Ukrainy - Veterinary Medicine of Ukraine, 2, 12-13 [in Ukrainian].

2.Hryshok, L.P., Nedosiekov, V.V., Polupan, I.M., Drozhzhe, Zh. M. \& Tsvilihovskyi, O.M. (2009). Problemy spetsyfichnoi profilaktyky skazu domashnikh tvaryn v Ukraini [Issues of specific prevention of rabies in pets in Ukraine]. Veterynarna medytsyna Ukrainy - Veterinary Medicine of Ukraine, 7, 11-13 [in Ukrainian].

3.Golik, M., Nedosekov, V. \& Polupan, I. (2016). Znachennya riznykh vydiv tvaryn u pidtrymtsi statsionarno-neblahopoluchnykh oseredkiv skazu na terytoriyi Chernihivskoyi oblasti [The value of the different species of animals in maintaining permanently rabies in Chernihiv region]. Biolohiya tvaryn - The animal biology, 18, 4, 129 [in Ukrainian]. 
4.Polupan, I., Bezymennyi, M., Golik, M., Drozhzhe, Z., Nychyk, S., \& Nedosekov, V. (2017). Spatial and temporal patterns of enzootic rabies on the territory of Chernihiv oblast of Ukraine. Journal for veterinary medicine, biotechnology and biosafety, 3, Iss. 2, 31-36.

5.Golik, M. O., Karlovska, K. P., Nedosekov, V. V., \& Polupan, I. M. (2015). Kharakterystyka epizootychnoyi sytuatsiyi zi skazu v Ukrayini [Characterisation of the epizootic situation for rabies in Ukraine]. Tvarynnytstvo Ukrayiny - Stock raising of Ukraine, 9, $16-19$ [in Ukrainian].

6. Guidance for research on oral rabies vaccines and Field application of oral vaccination of dogs against rabies. (2007). WHO.

7.Golik, M., Nedosekov, V., Ivanov, M.Yu. Sharai J.M., Nychyk, S. \& Polupan, I. (2017). Efektyvnist peroralnoyi imunizatsiyi sobaky proty skazu virusom "Brovarabis V-RG" [Effectiveness of oral immunization of dogs against rabies using vaccine Brovarabis V-RG]. Veterynarna biotehnologija - Veterinary biotechnology, 30, 41-47.

8.Surveying roaming dog populations: guidelines on methodology. (2007). WSPA.

9.Guidelines on stray dog population control. Terrestrial Animal Health Standards Commission. (2009). OIE.

10. Manual of Diagnostic Tests and Vaccines for Terrestrial Animals. (2013). oie.int. Retrieved from http: www.oie.int/fileadmin/Home/eng/Health_standards/tahm/2.01.13_RABIES.pdf.

\section{УДК 619:636.52/.58:616.41}

ГУРАЛЬСЬКА С.В., канд. вет. наук, доцент, e-mail: guralska@ ukr.net Житомирський національний агроекологічний університет

\section{ІМУНОГІСТОХІМІЯ ОРГАНІВ КРОВОТВОРЕННЯ ТА ІМУНОГЕНЕЗУ КУРЕЙ ЗА ІНФЕКЦІЙНОГО БРОНХІТУ}

У роботі з'ясовано імуногістохімічну характеристику субпопуляиій $C D 4^{+}, C D 8^{+}$, $C D 45 R A^{+}$та CD20+-лімфочитів у тимусі, селезінці, клоакальній сумиі, сліпокишкових мигдаликах, гардеровій залозі курей за інфекиійного бронхіту. У хворих курей в органах кровотворення та імуногенезу виявлено формування клітинного імунітету, про що свідчить збільшення кількості клітин з маркерами $\mathrm{CD}^{+}$ma $\mathrm{CD}^{+}$, a також активізацію гуморального типу імунної реакції, на що вказує значне збільшення кількості лімфоцитів з маркерами CD20+. При изьому у тимусі хворих курей 40 та 90-добового віку за нефрозонефритної форми інфекиійного бронхіту спостерігали достовірне $(p<0,001)$ зростання кількості лімфочитів з маркерами $\mathrm{CD}^{+}$у 2,08 та 2,28 рази відповідно, порівняно з клінічно здоровими, а також зниження імунорегуляторного індексу, щзо супроводжується активним функиіонуванням імунної системи організму на знищення чужорідного антигену.

Ключові слова кури, тимус, клоакальна сумка, селезінка, сліпокишкові мигдалики, гардерова залоза, субпопулящії лімфоцитів інфекиійний бронхіт.

Вступ. Інфекційний бронхіт птиці реєструється в усіх країнах світу i спричиняє значні економічні збитки промисловим i фермерським птахогосподарствам. Однією з актуальних проблем в птахівництві залишається вибір оптимальних програм імунізації птиці щодо інфекційного бронхіту курей [1-4]. Для розуміння патогенезу захворювання птиці останніми роками велика 